\title{
On the Anatomy of Two Palaeozoic Stems from India.
}

\author{
BY
}

\section{THE LATE RUTH HOLDEN.}

With Plates XVII-XX.

7 HE Glossopteris flora characteristic of the Permo-Carboniferous of the 1 Southern Hemisphere has received a considerable amount of attention of late years, but there are many problems connected with it which are still to be solved. Up to the present, the vast majority of specimens are known from impressions alone, in marked contrast to the contemporaneous flora of the north. This statement holds true especially for India, where nothing has been described in the way of anatomically preserved material. The Director of the Geological Survey, however, has sent to Professor Seward two specimens which are of exceptional interest from a comparative standpoint.

The first stem is from the Barakar of Deogarh ; it consists of several pieces, about $2 \mathrm{~cm}$. in diameter, embedded in a fine-grained grey sandstone. The bark has disappeared completely, and in places the structure of the wood has been obliterated by the vicissitudes of fossilization, but as a whole the state of preservation is excellent.

\section{DADOXYLON INDICUM, sp. nov.}

\section{Pith.}

As is common in Palaeozoic stems of the Cordaitean type, the pith is large, varying from 5 to $7 \mathrm{~mm}$. in diameter (Fig. $1, \mathrm{Pl}$. XVII). It differs, however, from Cordaites itself, and the nearly related Mesoxylon, in the absence of transverse diaphragms, thus agreeing with the only other known Permo-Carboniferous stems from the Southern Hemisphere-Dadoxylon Pedroi from Brazil ${ }^{1}$ and $D$. lafonense from the Falkland Islands. ${ }^{2}$ The tissues of the pith may be differentiated into an inner and an outer portion. The former is composed of irregularly squarish parenchyma cells, and the latter of slightly thicker walled, elongated elements, which are often filled with a dark substance and are probably secretory in nature. These cells are sometimes very long (Fig. 5), but are usually broken up by transverse

$$
1 \text { Zeiller (1895). } \quad 2 \text { Halle (1912). }
$$


or oblique walls (Fig. 4). Both D. Pedroi and D. lafonense have somewhat similar secretory elements, but they seem more in the nature of canals, the surrounding parenchyma cells being converted into a pseudo-sheath. These in question resemble rather the isolated cells of Lyginopteris.

Inserted between the pith proper and the vascular stele, there is a jacket of cells of a different nature. It varies in width, but generally speaking is best developed at the nodes. The smaller diameter of these elements serves to differentiate them in cross-sections (Figs. 2 and 7, P1. XVIII), while longitudinal sections reveal their characteristically reticulate, tracheoidal markings (Figs. 6 and I 7, Pl. XIX). They seem, in fact, to be identical with the transfusion tissue found in the leaves of Conifers, ${ }^{1}$ Casuarinales, ${ }^{2}$ \&c. Instances of their presence in stems are less common, but Rothert ${ }^{3}$ reports them in Cephalotaxus and Thompson ${ }^{4}$ in Ephedra. In all these cases, however, they occur as isolated cells, or small groups intermixed with parenchyma, rather than as a solid sheath, while in Megaloxylon ${ }^{5}$ they are not limited to the periphery, but extend throughout the pith. For strictly comparable structures we must go to Antarcticoxylon ${ }^{6}$ and to Mesoxylon Lomaxi and $M$. platypodium. ${ }^{7}$

\section{Leaf-traces.}

As regards leaf-traces, the absence of serial sections through the node renders it impossible to ascertain the conditions with exactness. It seems fairly certain, however, that the internodes were variable in length, a long one being followed by several very short ones. The result must have been that the leaves appeared superficially to be in whorls, but tangential sections prove that each was separated from the next by an appreciable distance. The course of the traces through the wood is almost horizontal until they approach the pith, when they bend steeply downward. The most striking feature is that they are always in pairs. A double trace is characteristic of practically all the Pteridosperms and Cordaitales, with significant variations. The most primitive condition is probably that of Lyginopteris, Heterangium, Medullosa, and Calamopitys, ${ }^{7}$ where the trace leaves the stele as a single strand and bifurcates either once or repeatedly in the pericycle and cortex. The next stage is represented by Poroxylon, ${ }^{8}$ where the division takes place some time before the trace leaves the margin of the pith, and the two strands pursue their outward course through the tissues of the secondary wood in close juxtaposition. Mesoxylon represents the next stage, for here not only are the two strands distinct at the margin of the pith but, as they penetrate the woody stele and pass out, they diverge more and more. Finally we come to our Indian

1 Jeffrey (1905).

4 Thompson (1912).

7 Scott (1912).
2 Boodle and Worsdell (1894).

${ }^{5}$ Seward (1899).

8 Bertrand (1889).
3 Rothert (1899).

6 Seward (1914). 
fossil, and here there is no indication that the two traces ever joined. In other words, there is always a distinct intercalary bundle, as in Ephedra ${ }^{1}$ or any of the living Angiosperms.

Various stages in the exit of the leaf-traces are shown in the photomicrographs. Fig. 7, Pl. XVIII, represents three bundles; the two outer ones are foliar and have commenced their journey towards the exterior, but are still pursuing a longitudinal course; in Fig. 8 they have become bent so that a transverse section of the stem cuts them almost longitudinally; Fig. 9, a tangential section of the stem, shows the traces still farther separated. On one occasion a trace was seen to divide as it passed out through the wood; it is represented in Fig. 12. A somewhat similar case was described by Dr. Scott in the case of $M$. platypodium, ${ }^{2}$ where the protoxylem of the strand divided while still in the wood,

\section{Primary Wood.}

In describing the structure of the wood, it will be simplest to start with the internode. As is shown in Fig. 2, Pl. XVII, the primary tissue is localized in bundles, of which there are 40 to 50 scattered around the circumference of the pith. All seem approximately the same size, without apparent differentiation into cauline and foliar. In transverse section there is no distinction between primary and secondary xylem, the elements being radially arranged throughout. Longitudinal sections, however, show that the protoxylem is strictly endarch and situated at the apex and along each side of the xylem wedges. Thus tangential sections of the bundle (Fig. I7, P1. XIX) show the larger spiral and reticulate metaxylem cells bounded on each side by the smaller lumened, often crushed, protoxylem-the whole enclosed on its inner face by the transfusional sheath described above. In radial section the centrifugal development of the bundle is even clearer (Fig. 6, Pl. XVII); at the extreme left is the sheath, its cells becoming longer and narrower towards the wood; next comes the protoxylem, and then the metaxylem, which through a transitional zone of from $I_{5}$ to 20 spiral and reticulate elements grades into the typical pitted tracheides of the secondary xylem. This arrangement holds for the bundles themselves, but in the interfascicular regions, as in Mesoxylon, the secondary wood abuts directly on the pith (Figs. 3 and 4). In the extensive transitional zone between primary and secondary wood proper, this Indian fossil resembles Cordaites, Mesoxylon, Poroxylon, \&c., but it differs from them all in the absence of centripetal wood.

We now come to the nodal region, and here conditions are somewhat complicated by the greater development of primary tissue. Instead of being limited to a few elements on the inner margin of the wood, there are distinct groups of primary elements at the apices of the xylem wedges.

1 Thompson (1912).

2 Scott and Maslen (1910). 
Figs. $\mathrm{I} 3$ and $14, \mathrm{Pl}$. XIX, represent two of these groups in transverse section, and Figs. 15 and 16 in longitudinal. The most striking feature about them is the large amount of xylem parenchyma occupying the centre of each group. As far as the writer is aware, such a condition is unique among stems of the Cordaitalean type, though it is characteristic of certain Palaeozoic ferns belonging to the Botryopterideae and allied forms. At the same time, it is worth noting that Mesoxylon shows a tendency in this direction (see especially 'Annals of Botany', vol. xxvi, Pl. XC, Fig. 23). It was stated above that during the long internodes there is no distinction between cauline and foliar bundles, but at the nodes a difference may be observed in the relative size of these primary groups, those associated with the leaf-traces being distinctly smaller. This may be made out in Fig. 7, Pl. XVIII.

\section{Secondary Wood.}

The secondary wood conforms in general with the cosmopolitan Palaeozoic genus Dadoxylon. The tracheides are small and unpitted tangentially, but the radial walls have crowded, one or two serial, bordered pits (Fig. I8, Pl. XIX). These are flattened by mutual contact until often they become roughly hexagonal in outline; the pore is elliptical. The rays are low ( 2 to 7 cells in vertical series), and throughout they are uniseriate(Fig. II, Pl. XVIII). This feature is shared by Cordaites and Mesoxylon, though it is in marked contrast with the broad-rayed Megaloxylon, Poroxylon, or Pitys. Like them too, the horizontal and end walls are thin and unpitted, but the lateral pits are unique. In all previously described woods of this age, the rays communicate with the tracheides by means of several small so-called 'piciform' pits; these are half bordered, and are in groups of 4 to 8 in each cross-field. In our Indian specimen, however, the pits are much larger, and have lost their borders, forming the typical 'Eiporen' of Gothan.' They are in groups of I to 4, the general tendency being for several small ones to fuse and form a single pit, as has been described by Bailey ${ }^{2}$ in various species of Pinus. Stages of this process are shown in Fig. I 8, Pl. XIX. The importance of the pitting of medullary rays has been emphasized, perhaps unduly, by Gothan (1. c.). Since 'Eiporen' such as are found here are characteristic of the genus Phyllocladus and its allies, he proposes to include all woods showing this feature in the form genus Phyllocladoxylon. The genus Xenoxylon is distinguished by having pits which are even larger, one such embracing the entire cross-field. Some of the pits of our fossil would bespeak its inclusion as Phyllocladoxylon, others as Xenoxylon. However convenient such a classification may be systematically, its value from a phylogenetic standpoint may be questioned. Among living Conifers, these large 'Eiporen' occur not only in the

$$
1 \text { Gothan (1905). }
$$

2 Bailey (1910). 
Podocarpineae, but also in the Taxodineous genus Sciadopitys and the Abietineous genus Pinus. Among extinct genera, they have been found by the writer in the Araucarian Paraphyllocladoxylon. ${ }^{1}$ From their presence in this fossil, they must be considered as an interesting case of parallel development, to which no phylogenetic significance should be attached.

Perhaps the most interesting feature of the secondary wood remains to be mentioned-the well-marked growth rings (Figs. I and 2, Pl. XVII). Arber was the first to call attention to this peculiarity in Permo-Carboniferous stems from Australia $;{ }^{2}$ since then Seward has called attention to the same phenomenon in Antarcticoxylon from the Antarctic, ${ }^{3}$ and Halle records rings in two genera from the Falkland Islands. ${ }^{4}$ At the same time, David White ${ }^{5}$ states that some at least of the South American forms resemble their contemporaries in the Northern Hemisphere in the uniform nature of the spring and summer wood. This fact is of especial interest in view of the wellknown mixture of northern and southern floras of Brazil and the Argentine, and may probably best be explained by assuming that the glaciation of this part of Gondwanaland was not as severe or as protracted as elsewhere. That this Indian stem should show distinct annual rings is to be expected from the particularly pure character of the Glossopteris flora of that country.

\section{Summary.}

To sum up, the chief points of interest in this fossil are:

Pith: large, non-discoid; differentiated into an inner parenchymatous and an outer, partly secretory, portion; separated from the vascular stele by a distinct transfusion sheath.

Leaf-traces: paired and invariably separated by an intercalary bundle.

Primary wood: localized into bundles; strictly endarch; large amount of protoxylem parenchyma at the nodes; broad transition zone between primary and secondary wood.

Secondary wood: typically coniferous; tracheides unpitted tangentially, covered radially by closely crowded, flattened pits with elliptical pores ; rays uniseriate, low, with large fusion pits on radial wall; annual rings distinct.

\section{CONCLUSION.}

A detailed comparison of this stem with others of the same age has been attempted as the different structures were described, and it is evident that it is closely allied to the other members of the Cordaitales, though it is identical with none. To indicate this relationship it may be called Dadoxylon indicum, with the diagnosis as given above. This stem is not without its

1 Holden (1913).

2 Arber (1905).

5 White (1908).
${ }^{3}$ Seward (1914). 
bearing on the question of the identity of Cordaites and Noeggerathiopsis. The latter genus was founded by Feistmantel for leaves which are similar to Cordaites, but differ in certain details of nervation. It occurs in the chief Gondwana formations-India, S. America, and New South Wales, and has been cited as one of the examples of the difference between northern and southern floras in Permo-Carboniferous times. Recently there has been a tendency to merge this genus with Cordaites. A discussion of the pros and cons of the situation is given by Arber ${ }^{1}$ and Zalessky, ${ }^{2}$ which it is not necessary to repeat. It is sufficient to note here that the anatomy of this Indian stem, which probably bore Noeggerathiopsis leaves, indicates that the two genera are very closely allied, but not identical.

\section{DADOXYLON BENGALENSE, sp. nov.}

The second stem is from the East Indian Coal Company's colliery at Brahmanbarari in the Jharia coalfield, Bengal. Its source indicates that it is of Barakar (Permo-Carboniferous) age. The cross-section is slightly oval, due probably to the pressure to which the stem was subjected; the greatest diameter is 4 inches, and the length of the smallest of the three pieces, $5 \frac{1}{2}$ inches. Their great weight is very noticeable, the specific gravity being $3 \cdot 6$, and in this connexion the following excerpt from a letter by Mr. Fermer of the Indian Geological Survey is of interest:

' The specimen was tested chemically by Mr. G. G. Narke, a student from Nagpur, working in the Geological Survey Laboratory, and found to consist mainly of iron carbonate, with a certain amount of manganese, calcium, and magnesium. The specific gravity of siderite, as given by Dana, is $3 \cdot 83-3 \cdot 88$. There is no doubt that the substance in which the wood is fossilized is siderite, and the somewhat lower specific gravity of the specimen as compared with true siderite is probably to be explained as due to the cavities that the fossil is seen to contain in places when examined in thin sections under the microscope. It is probable that the substances other than iron, present in the specimen, in part isomorphously replace some of the iron of the chalybite. But from the appearance of one of the sections under reflected light, I should think that a portion at least of the manganese is present in the form of manganese oxide filling interspaces in the fossil. It is to be noticed that the colour of the specimens as examined in hand specimens is black. It has not been determined whether this colour is due to such mechanically included manganese oxide or to mechanically distributed free carbon remaining from the original wood.'

With this description of its external appearance, we may pass on to consider its internal structures. Unfortunately the pith and tissues immediately around it have disappeared, so that it is impossible to obtain any
1 Arber (1905).
${ }^{2}$ Zalessky (1912). 
information in regard to the primary bundles, either at the medulla or during their exit as leaf-traces. It may be inferred, however, from the absence of foliar strands in the innermost zone of xylem which has been preserved, that they were ephemeral in their nature, rather than persisting for several years after the fall of the leaf itself, as is the case in certain Mesozoic and living Conifers. In places, traces of the bark may be found, but so indifferent is the state of preservation that no details of its structure could be ascertained. The woody cylinder itself has suffered less from the ravages of time, and a microscopic study reveals all the details of its organization. The most striking feature shown in the transverse section (Fig. 1, Pl. XVII) is the presence of distinct annual rings. That these are true growth rings cannot be questioned ; they surround the entire stem, and it is possible to trace the gradual diminution in size and thickness of wall in passing from spring to summer tracheides, followed by the abrupt transition to the larger lumened, thin-walled elements of the ensuing year. The rings are remarkably broad, extending sometimes from 10 to $12 \mathrm{~mm}$. This character is more striking when compared with that of living Conifers. In measurements made by the writer on a representative collection of woods, the average width of annual ring was found to be from $\mathrm{I}$ to $3 \mathrm{~mm}$. In many pines $4 \mathrm{~mm}$. is not uncommon, and in the Podocarps and Taxads it is usually as low as $0.5 \mathrm{~mm}$. Penhallow ${ }^{1}$ has given figures agreeing in the main with these. The only cases at all comparable with this Indian specimen were Cupressinoxylon chayennense (Cretaceous) and Pityoxylon Aldersoni (Tertiary), the rings of the former being $10 \mathrm{~mm}$. in width, and of the latter 6-9 $\mathrm{mm}$. To return to the wood in question, their number indicates that it had reached an age of five years, but, as noted above, the tissues adjacent to the pith have disappeared, and it is possible that one or two years' increment may thus have been obliterated. Even so, a much more rapid rate of growth is indicated than that shown by the Conifers of to-day.

The wood itself conforms in a general way to the Dadoxylon type so common at that time throughout the world. The tracheides are small, and the pits seem confined to the radial wall. The size and arrangement of these pits are, however, quite distinctive, and serve to differentiate this specimen from others of a similar nature. It will be noticed from Fig. 3 that they practically never stand alone, but are rather in groups of $2-5$. Two is the prevailing number, and in this case they are almost invariably opposite. Groups of three are also frequently seen, either all abreast, or one between and above the others. Rarely four may be seen on the same horizontal line, but this is unusual, though groups of four are not uncommon. In no case is there the slightest indication of a 'bar' or 'rim of Sanio' between the pairs of opposite pits. This grouped condition is characteristic

1 Penhallow (1907). 
of the greater part of each tracheide, but towards the ends it is often replaced by the more crowded position which obtains in other Araucarioxyla. In the photograph, Fig. $2 \mathrm{I}, \mathrm{Pl}$. XX, the small size of the pits is very striking, but it seems probable that the state of preservation somewhat unduly accentuates this appearance. Examination of a number of slides has revealed a few places where the structure of the pit is perfectly retained. From these it is evident that originally they were closely compressed and flattened where in contact; the outside of the border was angular, while the actual opening was an elliptical slit. Further, as in all Palaeozoic woods, there was probably no torus. During the process of fossilization, the aperture was enlarged until it has become circular, the inner margin of the border was darkened so that it now appears as a black rim, while the outer, originally angular, margin is indistinguishable. Gothan ${ }^{1}$ figures a specimen where a similar darkening of the inside of the border, coupled with the obliteration of the outside, causes the pits to appear more remote than was actually the case. Tangential sections indicate that this interpretation of the structures in question is the correct one. The beaded appearance of the wall (Fig. 22, Pl. XX) is due to the fact that the entire border has disappeared, leaving a much enlarged aperture to represent the former extent of the whole pit. Nevertheless, by actual measurement, the size of the pits is extraordinarily small. Gothan (1. c. p. 20) gives the dimensions of a number of typical Araucarioxyla varying from $16 \mu$ in diameter in A. Keuperianus to 8-9 $\mu$ in $A$. Tchihatcheffiamus; and it is noteworthy that in this Indian specimen the pits are smaller still, having an average diameter of only $4 \mu$.

The medullary rays (Figs. 2 and 4 , Pl. XVII) present nothing of especial interest. They are always uniseriate, and in height range from $\mathrm{I}$ to 20 cells, with an average of 6 to 7 . The walls are thin and unpitted, except where in contact with tracheides. Here the pits are in groups of 2 to 7 to each crossfield ; they are small, half bordered, with an elliptical aperture. It might be suggested that the groups described above as characteristic of the radial walls of the tracheides are really caused by rays which crossed at these points, and that the pits in question are not those from tracheide to tracheide, but from tracheide to ray. It is true that the structure and mode of occurrence are similar, but the fact that the groups on adjoining tracheides are not on the same horizontal line indicates that this explanation is not the correct one. Further, tangential sections (Fig. 4) show conclusively that the grouping on the tracheides bears no relation to the presence or absence of rays, and that the pits are really from tracheide to tracheide.

Having completed the description of this fossil, it is apposite to consider its relation to other similar specimens. The absence of primary tissue ${ }^{1}$ Gothan (1905). 
renders any real comparison impossible, but the grouping of the radial tracheary pits recalls certain Devonian stems now referred to the genus Callixylon. In I 909 Zalessky $^{1}$ described a new stem of the Pitys type under the name of Dadoxylon Trifilievi; in I9I I ${ }^{2}$ he published further observations on this stem and decided that its structure was sufficiently distinctive to warrant the inception of the new genus Callixylon, for, in addition to the numerous bundles of primary tissue surrounding the pith, the secondary xylem is distinguished by the peculiar distribution of the radial pits. They are of the normal Dadoxylon type,-closely compressed and flattened to a hexagonal outline, but instead of being scattered uniformly over the cellwall, they are localized in groups of six to thirteen or more. The groups of one tracheide are on the same horizontal line as those of the next, and give a characteristic radially banded appearance to the wood. In this respect Zalessky's stem closely resembles one described by Newberry from the Upper Devonian of the State of Ohio, U.S.A., since named by Penhallow ${ }^{3}$ Cordaites Newberryi. In I9I4 Elkins and Wieland ${ }^{4}$ discovered another beautifully preserved specimen of the same general type from the Upper Devonian of Indiana and, on the basis of the pitting, included both stems in the genus Callixylon. If we accepted their view that bordered pits are sufficient to define the limits of a genus the Indian fossil should also be referred to Callixylon. To facilitate comparison the following table may be of value :

\section{Callixylon (secondary wood).}

C. Newberryi.

Annual rings

Rays

Tangential pits of tracheides

Radial pits of Pit circular, $9 \mu$ in tracheides
C. Orveni.

+ ; 6 in 5 mm.

I-2 seriate

I-40 cells high

6-8 pits to each cross-field diam. ; pore diagonal

$2-3$ seriate groups
of $6-13$ groups
banded radially
Pit circular elliptical or irregularly flattened, IO-I I $\mu$ in diam.; pore diagonal

I-4 seriate groups of 3-40 groups banded radially
C. Trifilievi.

Indian stem.

+ ; IO-I 2 mm.wide

I seriate

I -20 cells high

2-7 pits to each cross-field

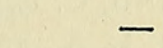

It seems to the writer, however, that to combine these into one genus is to take an exaggerated view of the importance of radial pitting. While unquestionably constant, its value as a test for affinities is doubtful. Thus

1 Zalessky (1909).

3 Penhallow (1907).
2 Zalessky (1911).

4 Elkins and W'jeland (1914). 
in the genus Pinus the pits are usually opposite and distant, but Professor Groom ${ }^{1}$ has recently described one species from India, $P$. Merkusii, where they are in groups of three or four, comparing this condition with that of Cordaites Newberryi. Here the variation is within the genus, but it may occur even within a single species; e.g. some of the Abietineae which have stem pits of the normal Pinus type have them grouped in the root as they are in Groom's stems. Were these woods discovered in the fossil state, and pitting used as the criterion for classification, the stem of Pinus Merkusii would inevitably be put with the root of Cedrus, and so on. Assuming that the pitting of these Palaeozoic Gymnosperms is of the same diagnostic value as that of living Conifers, it seems an unwarranted step to include these four specimens in the genus Callixylon, especially when their ages vary from Devonian to Permo-Carboniferous and their sources from America to India.

Accordingly, it does not seem advisable to do more than refer this Indian stem to the genus Dadoxylon, with the specific name bengalense to denote its source, and the following diagnosis:

Dadoxylon bengalense, sp. nov. Annual rings present. Pits of the radial walls of the tracheides very small $(4 \mu$ in diameter) and arranged in groups of $2-7$.

In conclusion, I wish to thank Professor Seward for an opportunity to study and describe these stems, and for many suggestions in regard to them.

\section{LITERATURE CITED.}

Arber, E. A. N. (1905): Catalogue of the Fossil Plants of the Glossopteris Flora in the Department of Geology, British Museum (Natural History), London.

Bailey, I. W. (1910): Anatomical Characters in the Evolution of Pinus. American Naturalist, vol. xliv, May.

Bertrand, C. E. (1889): Les Poroxylons. Ann. d. l. Soc. Belge d. Microscopie, Bruxelles.

Boodle, L. A., and Worsdell, W. C. (1894): On the Comparative Anatomy of the Casuarineae, with special reference to the Gnetaceae and Cupuliferae. Ann. of Bot., vol. viii.

ElKins, M. G., and Wieland, G. R. (1914): Cordaitean Wood from the Indiana Black Shale. Am. Jour. of Science, vol. xxxviii, July.

Gothan, W. (1905) : Zur Anatomie lebender und fossiler Gymnospermen-Hölzer. Abh. K. Preuss. Geol. Landesanst. (N. F.), Heft 44, Berlin.

Groom, P., and Rushton (1913) : East Indian Species of Pimus. Jour. Linn. Soc., vol. xli, p. 457.

HALle, T. G. (1912): On the Geological Structure and History of the Falkland Islands. Bull. Geol. Inst. Univ. Upsala, vol. xi, p. II 5 .

Holden, R. (1913): Jurassic Coniferous Woods from Yorkshire. Ann. of Bot., vol. xxvii, p. Io7.

Jeffrey, E. C. (1905): Comparative Anatomy and Phylogeny of the Coniferales. Pt. II. The Abietineae. Mem. Bost. Soc. Nat. Hist., vol. vi, p. 2 I.

Maslen, A. J. (1911): Structure of Mesoxylon Sutcliffi. Ann. of Bot., vol. xxv, p. $38 \mathrm{r}$.

Penhallow, D. P. (1907): North American Gymnosperms. Boston.

1 Groom and Rushton (1913). 
RotherT (1899): Ueber parenchymatische Tracheiden und Harzgänge im Mark von CephalotaxusArten. Ber. deutsch. Bot. Ges., vol. xvii, p. 275.

Scott, D. H., and Maslen, A. J. (1910): On Mesoxylon, a New Genus of Cordaitales. Ann. of Bot., vol. xxiv, p. 230.

ScotT, D. H. (1912): Structure of Mesoxylon Lomaxii and M. poroxyloides. Ibid., vol. xxvi, p. IOII.

(1912): Primitive Structures of certain Palaeozoic stems. Trans. Roy. Soc. Edinb., vol. xl, Pt. II, No. I7.

Seward, A. C. (1899): Notes on the Binney Collection of Coal-Measure Plants. Pt. II. Proc. Camb. Phil. Soc., vol. $x$, Pt. III, p. $15^{8}$.

(1914): Antarctic Fossil Plants. British Antarctic ('Terra Nova') Expedition, I9Io, Nat. Hist. Report, Geology, vol. i, No. I.

Thompson, W. P. (1912): Anatomy and Relationships of the Gnetales. I. Ephedra. Ann. of Bot., vol. xxvi, October.

White, D. (1908): Fossil flora of the Coal Measures of Brazil. Commissão de Estudos das Minas de Carvão de Pedra do Brazil, Rio de Janeiro.

Zalessky, M. (1909) : Communication préliminaire sur un nouvean Dadoxylon. Bull. de l'Acad. Imp. d. Sciences de St. Pétersbourg.

(1911): Étude sur l'anatomie du Dadoxylon Tchihatcheff, Goepp. sp. Mémoires du Comité Géologique de Russie, nouvelle série, Livr. 68, St. Pétersbourg.

(1912): Sur le Cordaites aequalis, Goepp., sp. de Sibérie et sur son identité avec Noeggerathiopsis Hislopi, Bunb., sp. de la Flore du Gondwana. Mém. Com. Géol. St. Pétersbourg (N. S.), Livr. 86.

\section{EXPLANATION OF PLATES XVII-XX.}

Illustrating Miss Holden's paper on the Anatomy of Two Palaeozoic Stems from India.

\section{PLATE XVII.}

Fig. I. Transverse section of entire stem, showing large pith, surrounded by vascular tissue with well-marked annual rings.

Fig. 2. Transverse section at internode, showing secretory cells in the pith, small lumened transfusional sheath, primary wood in bundles, succeeded by radially arranged secondary wood.

Fig. 3. Longitudinal section through interfascicular region, showing secondary wood abutting directly on the pith.

Fig. 4. Longitudinal section, showing usual character of secretory cells in pith.

Fig. 5. Longitudinal section, showing unusually elongated secretory cells.

Fig. 6. Longitudinal section through apex of bundle, showing its endarch nature-at extreme lett, transfusional elements with tracheoidal markings, becoming more elongated centrifugally; next, protoxylem, metaxylem, and, finally, scalariform elements grading into secondary wood.

\section{PLATE XVIII.}

Fig. 7. Transverse section at node, showing two outgoing leaf-traces, separated by a large cauline bundle.

Fig. 8. Transverse section at a slightly higher level, where the two leaf-traces have turned sharply in a horizontal direction.

Fig. 9. Tangential section, showing the two traces widely separated in the secondary wood.

Fig. Io. Tangential section including the pith and innermost part of two bundles.

Fig. II. Tangential section of leaf-trace embedded in secondary wood, showing low, uniseriate rays.

Fig. 12. Tangential section, showing branching leaf-trace. 


\section{Holden.-Anatomy of Two Palaeozoic Stems from India.}

\section{PLATE XIX.}

Fig. I3. Transverse section of bundle at node, showing group of primary elements, with large amount of protoxylem parenchyma, surrounded by transfusion sheath.

Fig. 14. Transverse section of another similar bundle.

Fig. 15. Longitudinal radial section through apex of bundle, showing especially protoxylem parenchyma, and broad transitional region of scalariform elements before reaching typical secondary wood.

Fig. 16. Longitudinal section through group of primary elements, to show character of protoxylem parenchyma.

Fig. I 7. One of the bundles of Fig. Io more highly magnified, to show how the protoxylem extends down the flanks of the bundle, so that a tangential section includes protoxylem on each side of the metaxylem.

Fig. 18. Radial longitudinal section of secondary wood, showing closely crowded bordered pits of the tracheides and large fusion pits on radial walls of the rays.

\section{PLATE XX.}

Fig. 19. Dadoxylon bengalense: transverse section, showing annual rings.

Fig. 20. Dadoxylon bengalense: radial longitudinal section, showing general coniferous type of wood.

Fig. 2I. Dadoxyion bengalense: radial section, showing size and arrangement of pits.

Fig. 22. Dadoxylon bengalense: tangential section, showing low rays and bead-like characters of tracheide walls, caused by radial pits. 


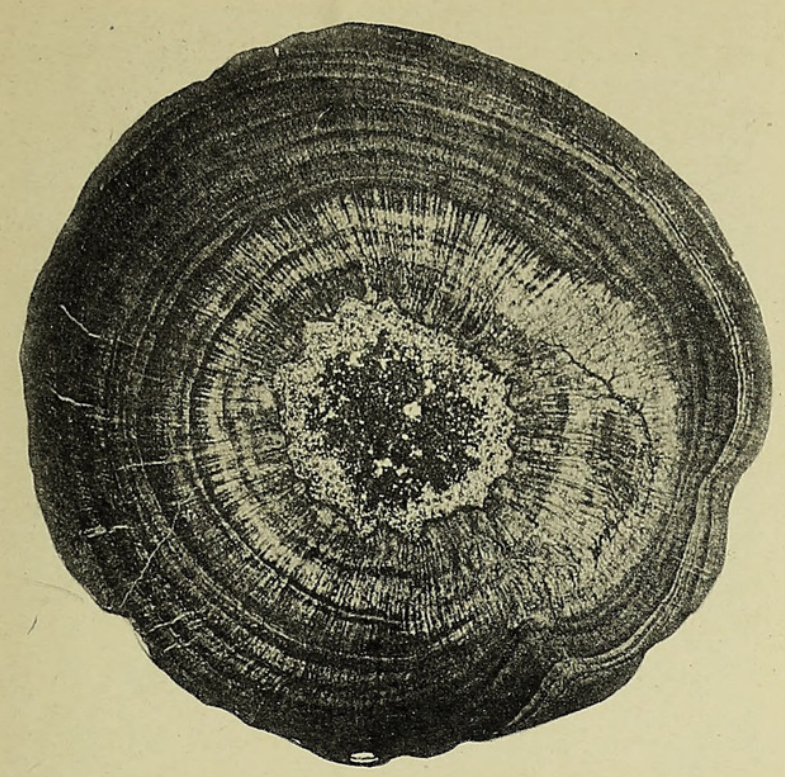

1.
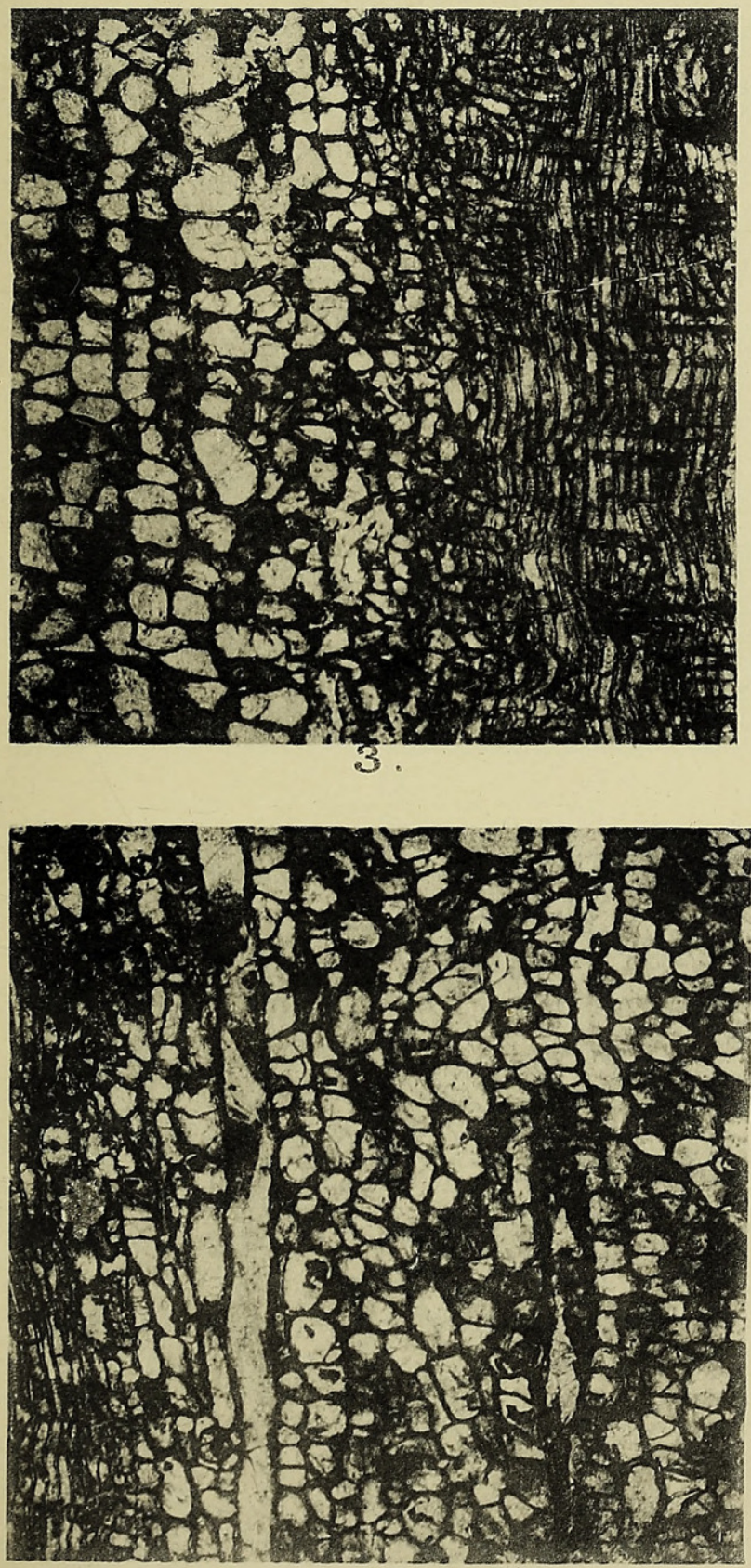

5
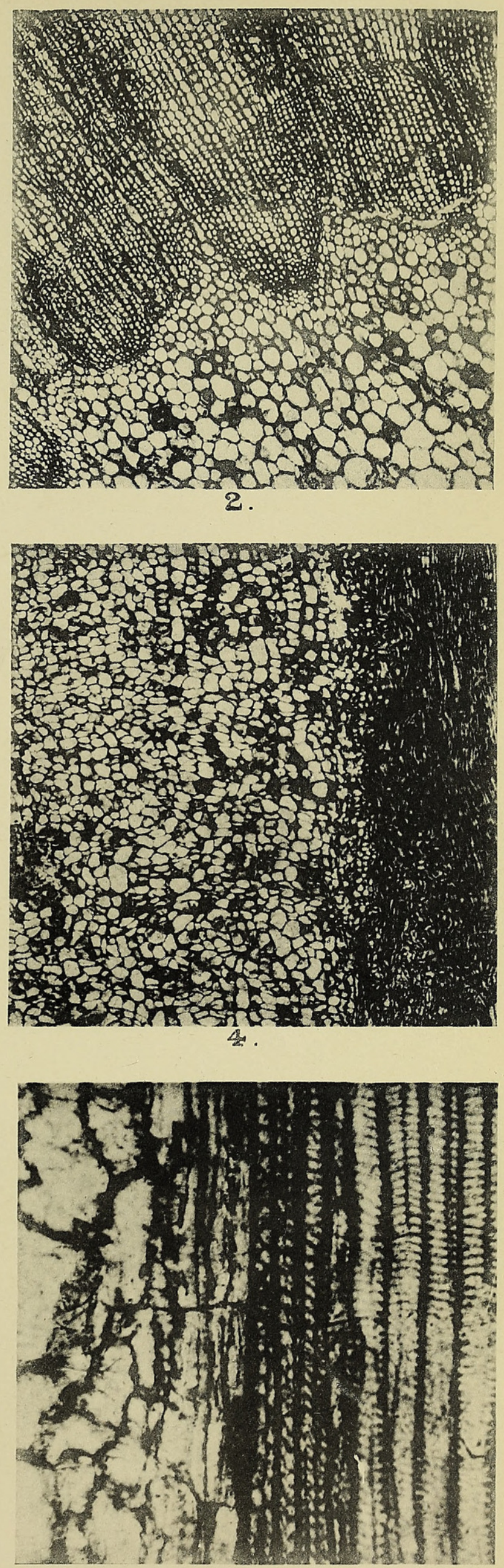

6. 


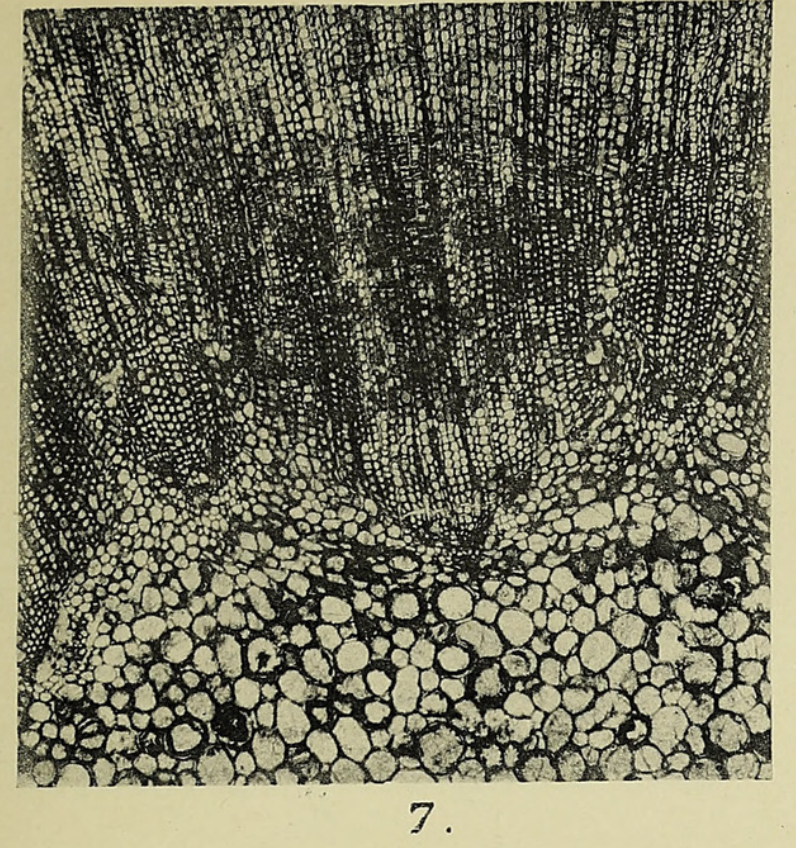

(5)

(2)

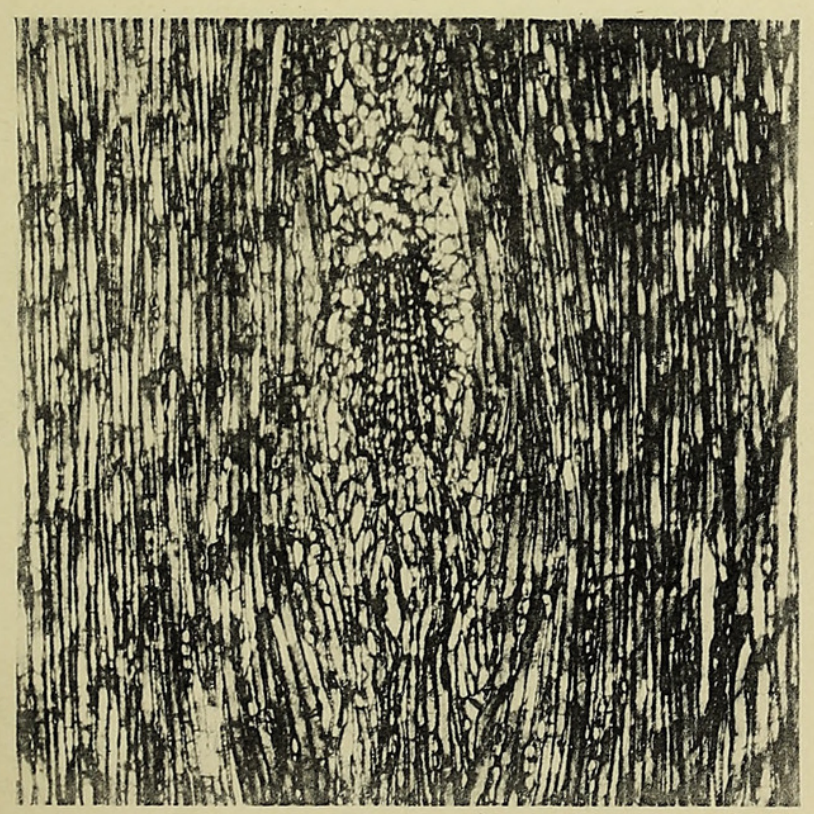

1\%.

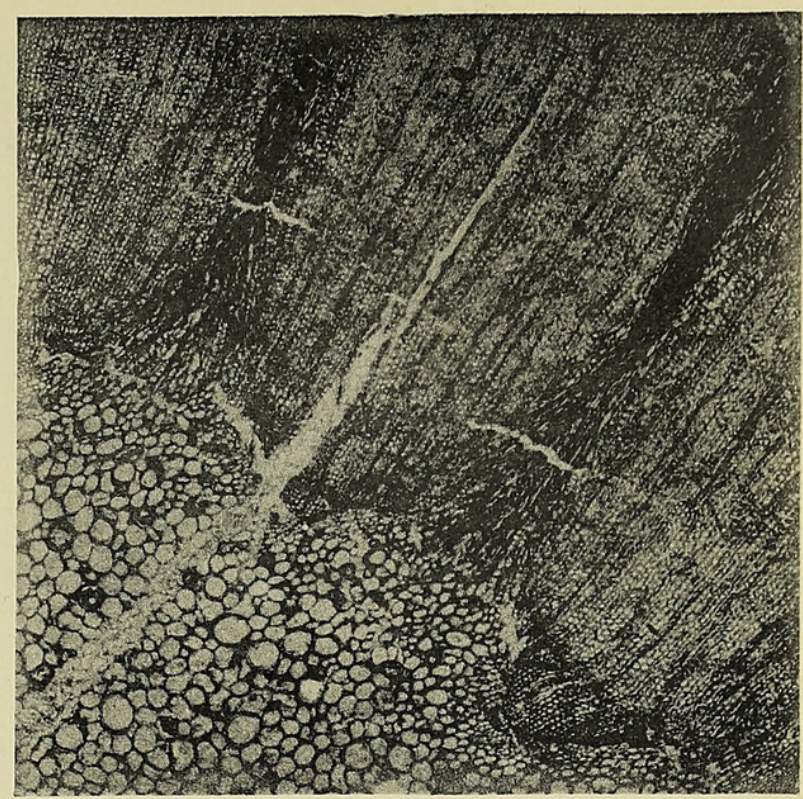

8

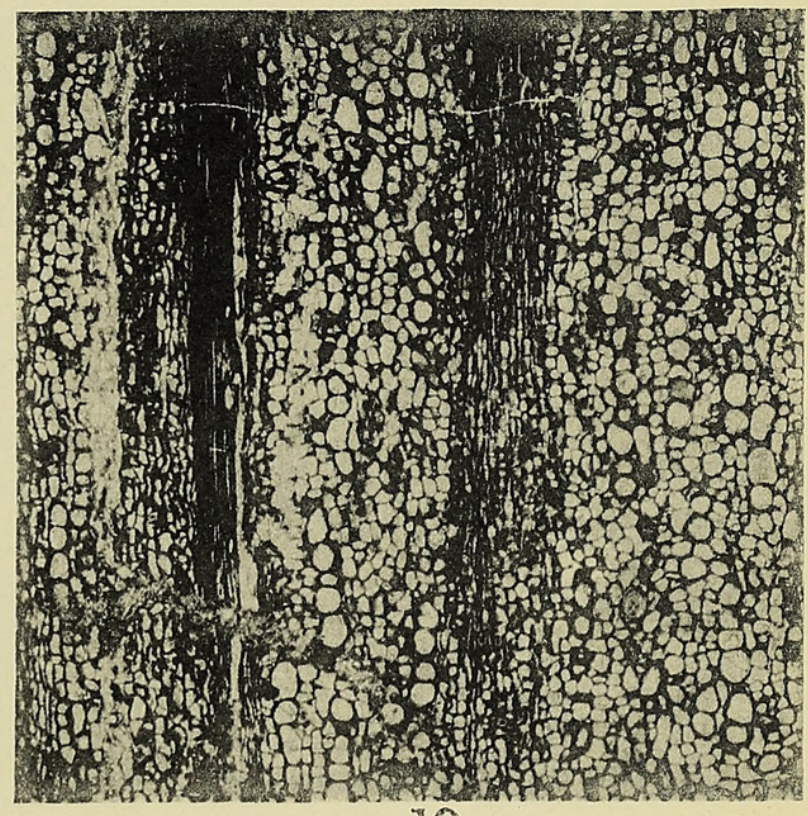

10.

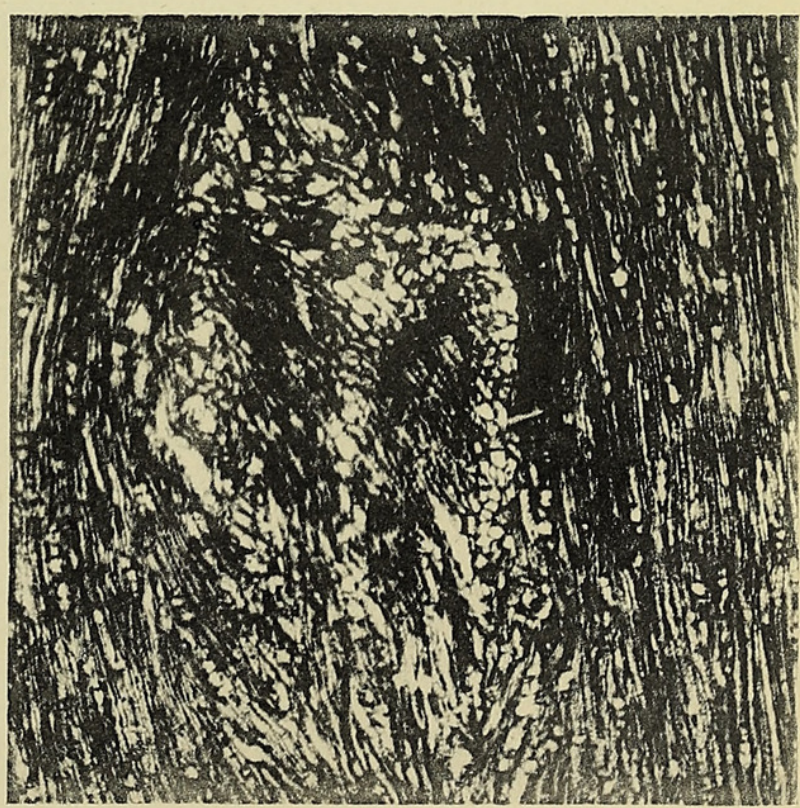

12 

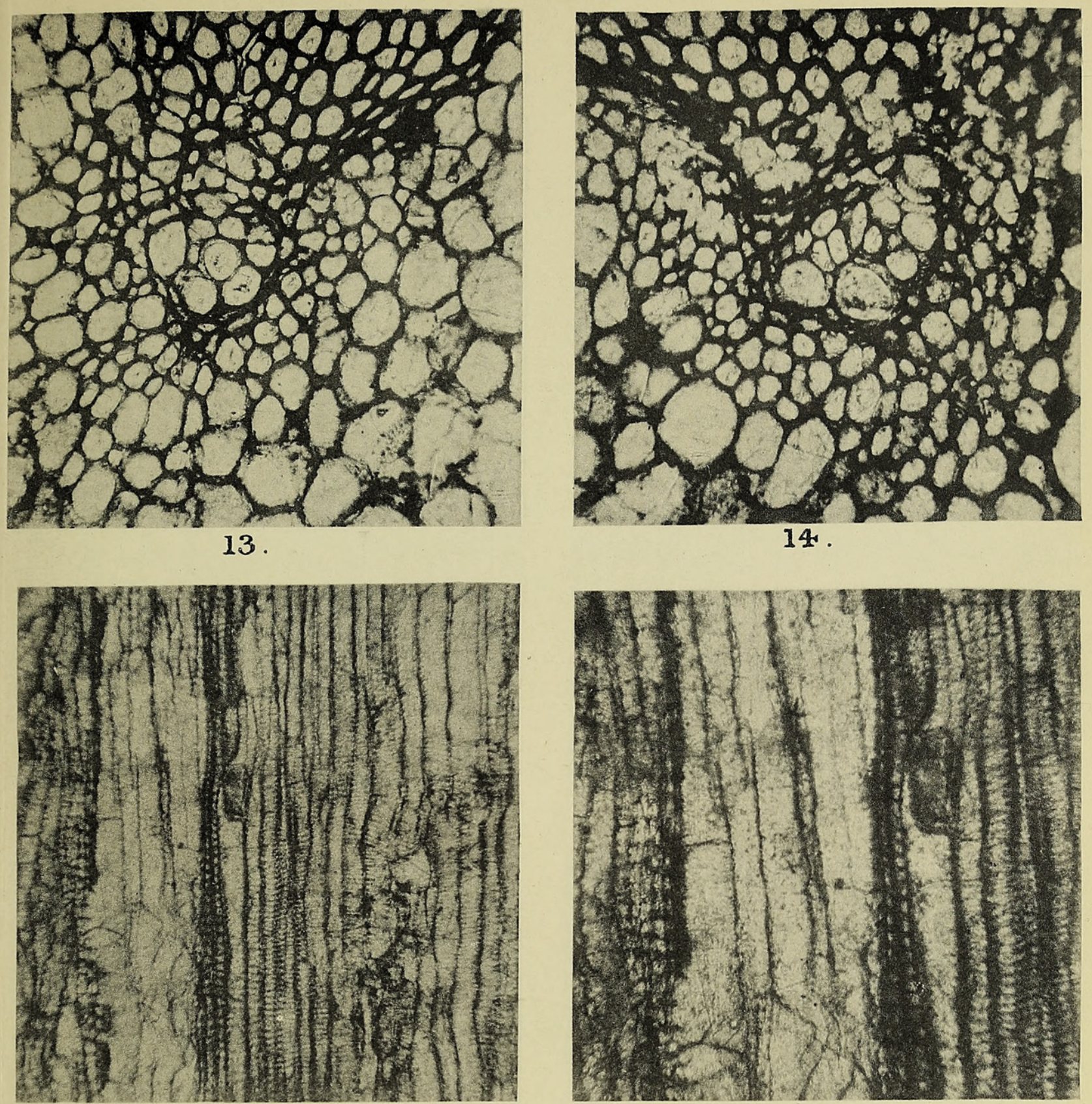

15.

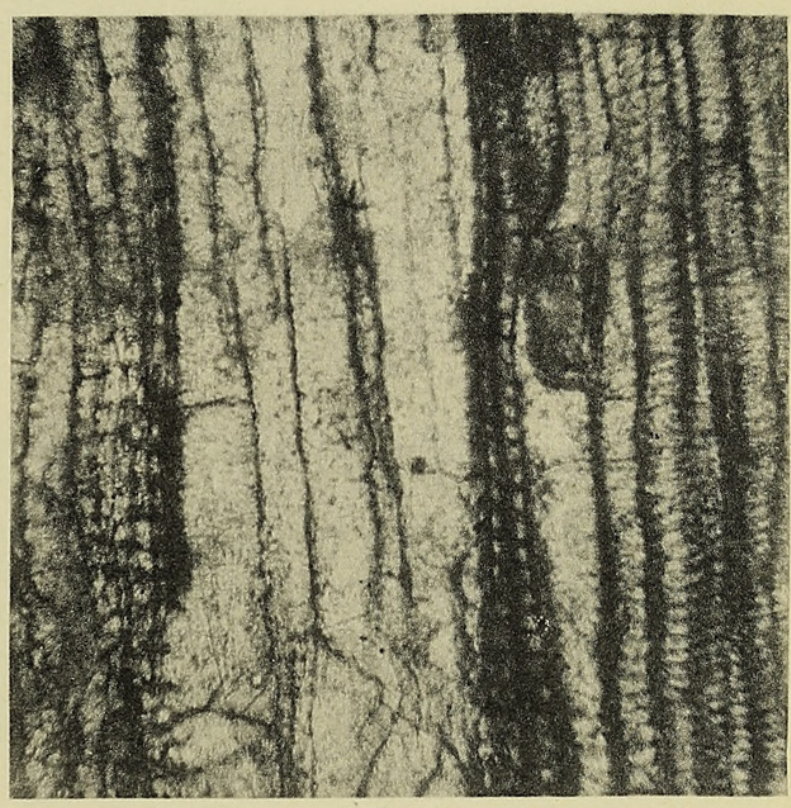
16.
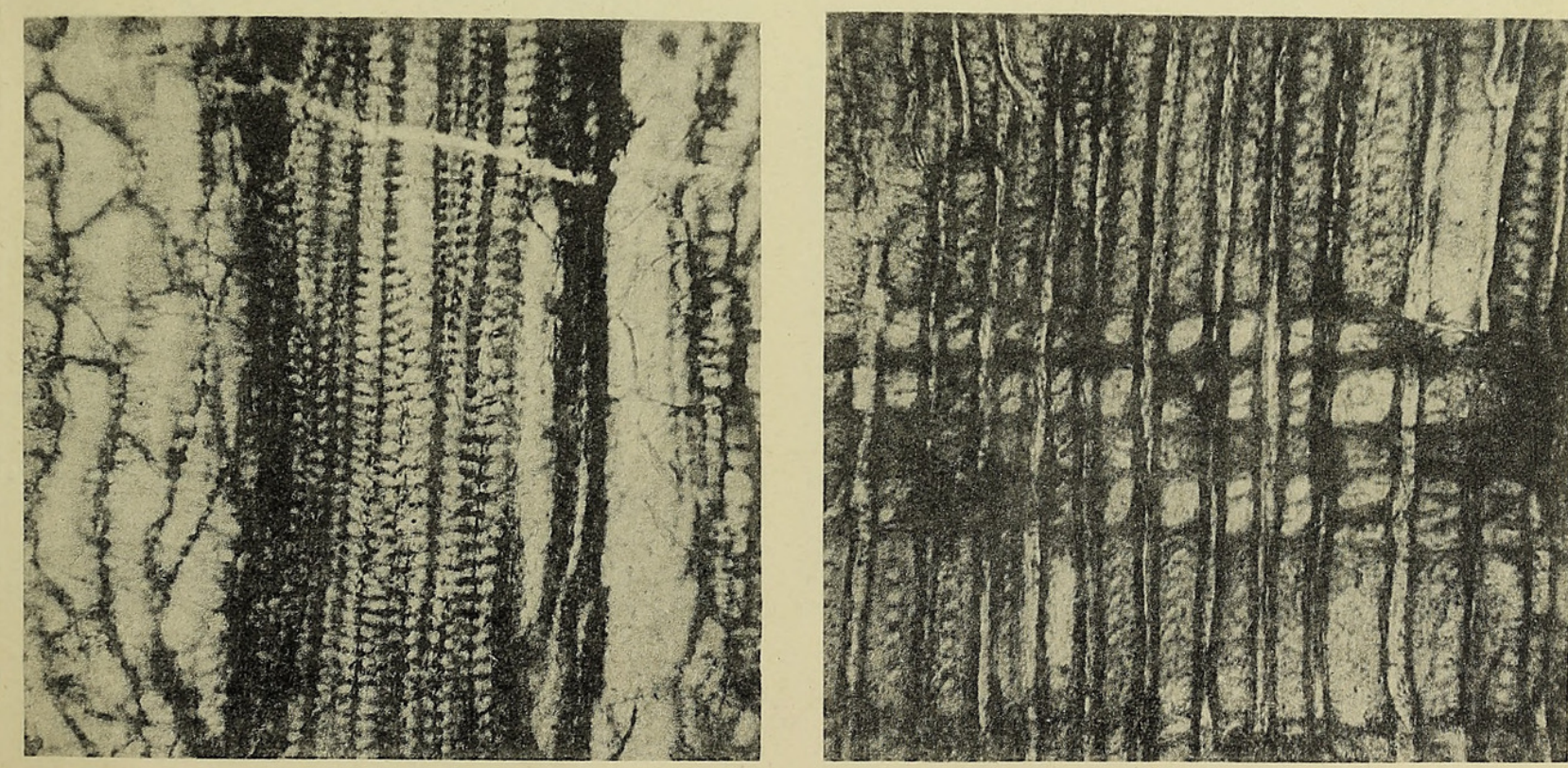


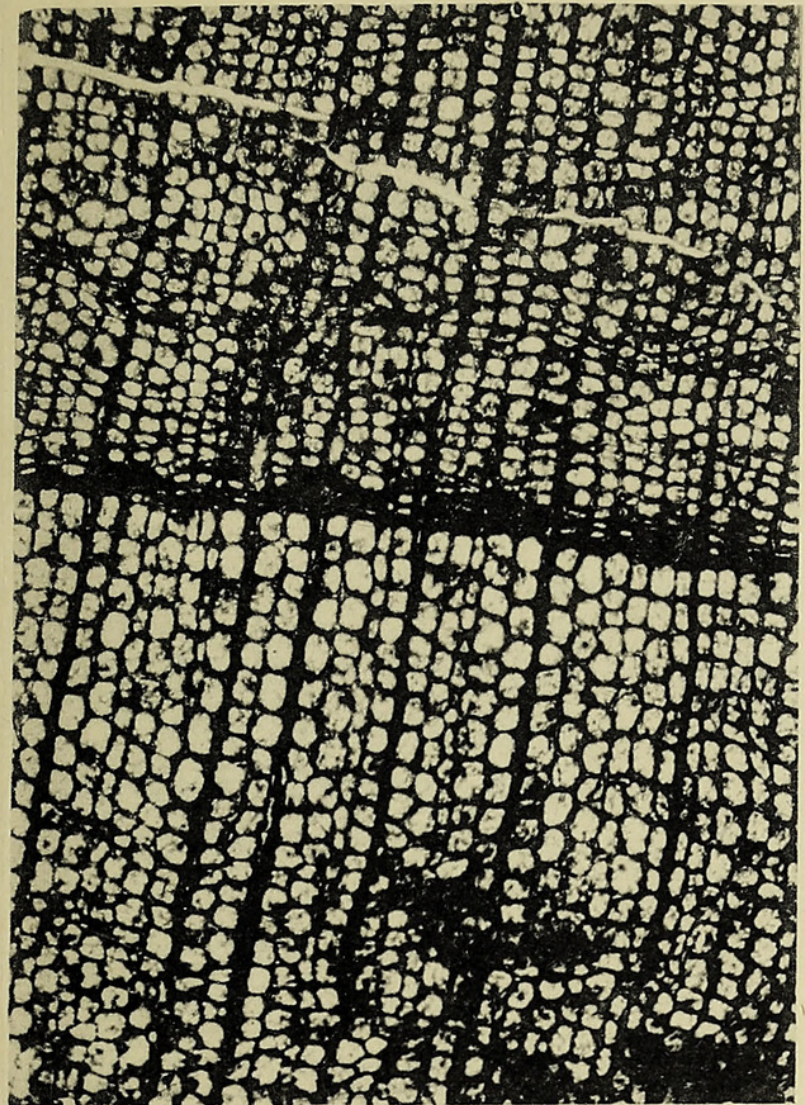

19.

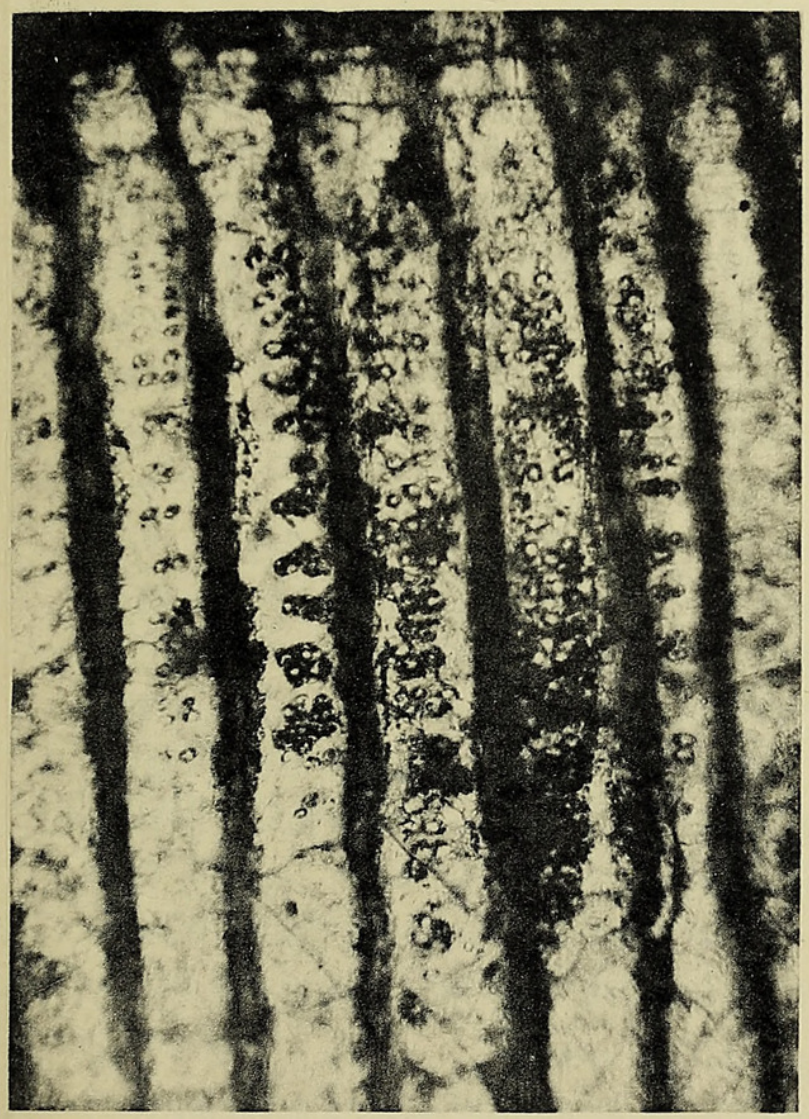

21.

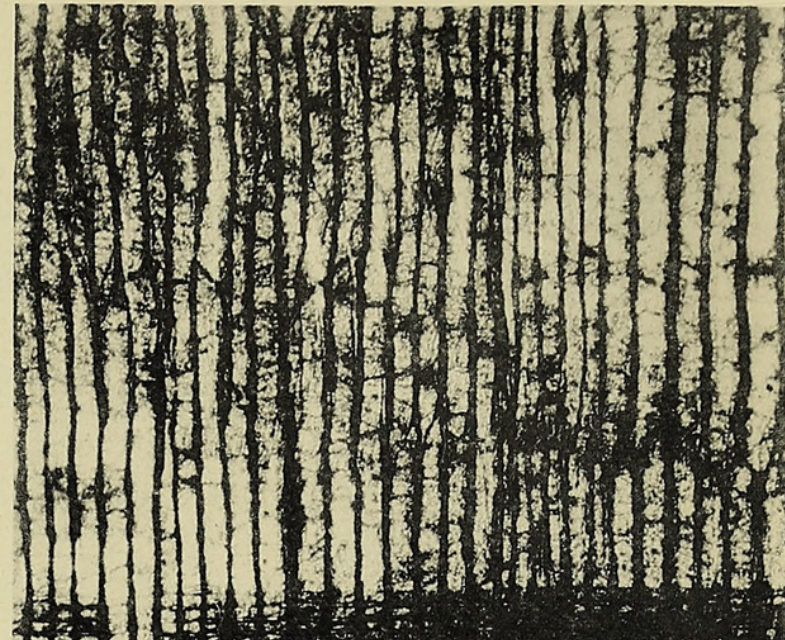

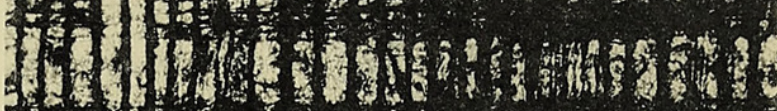

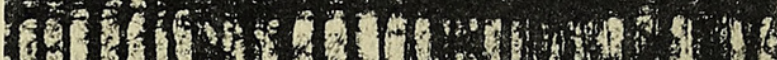

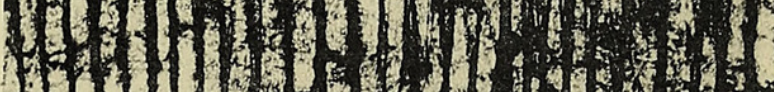

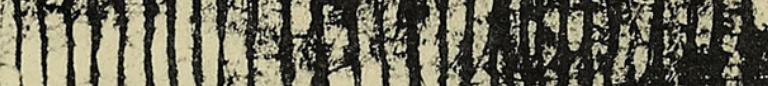
1. 20

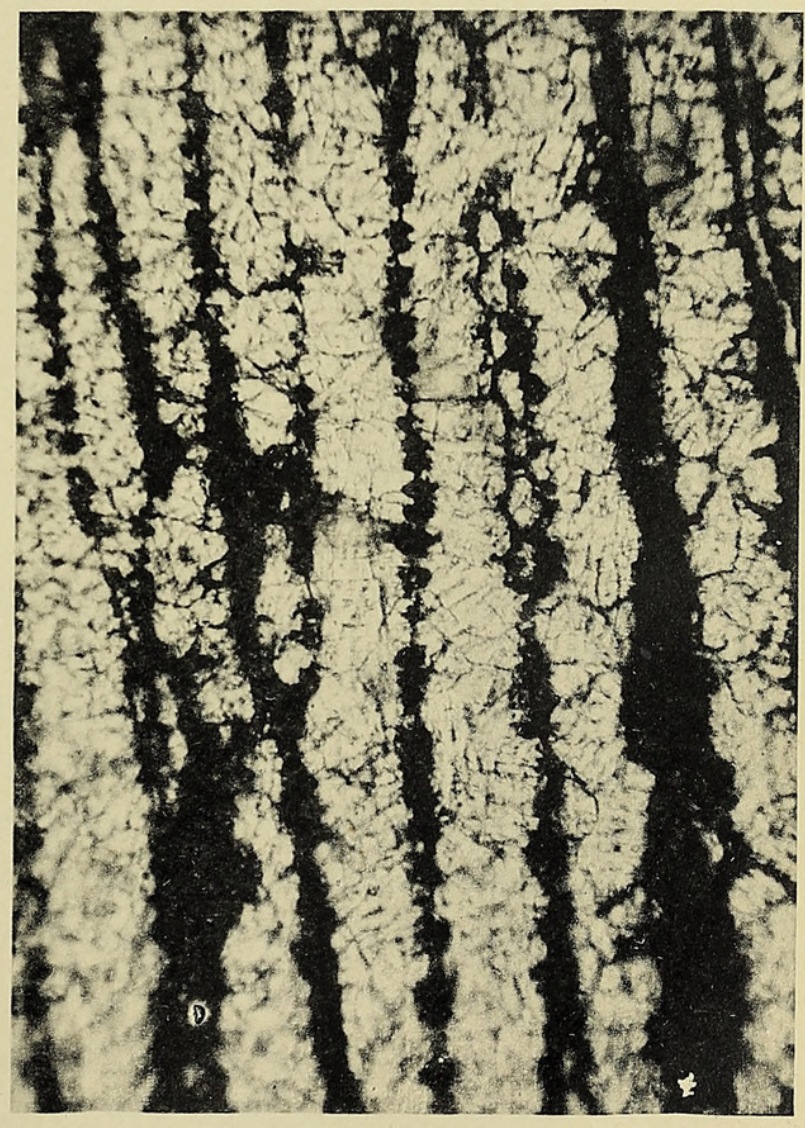
22 


\section{$2 \mathrm{BHL}$ Biodiversity Heritage Library}

Holden, Ruth. 1917. "On the anatomy of two Palaeozoic stems from India." Annals of botany 31, 315-326.

https://doi.org/10.1093/oxfordjournals.aob.a089649.

View This Item Online: https://www.biodiversitylibrary.org/item/232813

DOI: https://doi.org/10.1093/oxfordjournals.aob.a089649

Permalink: https://www.biodiversitylibrary.org/partpdf/320192

\section{Holding Institution}

Smithsonian Libraries

\section{Sponsored by}

Biodiversity Heritage Library

\section{Copyright \& Reuse}

Copyright Status: Not in copyright. The BHL knows of no copyright restrictions on this item.

This document was created from content at the Biodiversity Heritage Library, the world's largest open access digital library for biodiversity literature and archives. Visit BHL at https://www.biodiversitylibrary.org. 